\title{
Relationship between organizational culture and performance among German multinational companies in Mexico
}

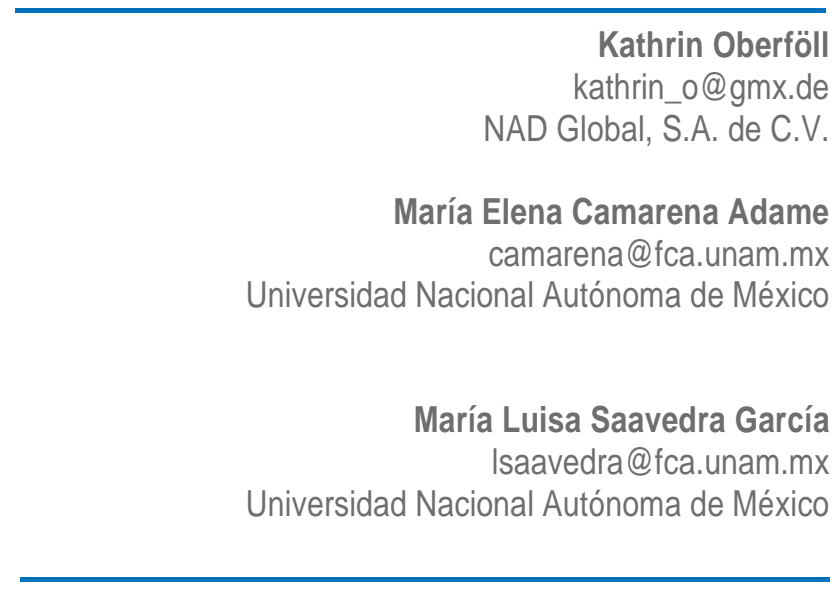

\begin{abstract}
The objective of this research is to determine if there is a relationship between organizational culture and organizational performance in German multinational companies operating in Mexico. To this end, we use a multiple case study, analyzing five German multinational autoparts companies with operations in Mexico, applying a questionnaire to executives at each of the five companies and to 232 employees at one of them. Our main finding is that there is a significant relationship between organizational culture variables and organizational performance variables, such as turnover, job satisfaction, satisfaction with the company, and sales. The study illustrates the importance of promoting human resources policies aimed at increasing employee satisfaction, and studies should be carried out to identify the triggers of satisfaction with greater precision, which may improve the performance of this type of company. The main limitation of this work is that as a case study, the results cannot be generalized; however, very few previous studies have attempted to establish the relationship between culture and performance in the Mexican context, so this study constitutes a milestone for knowledge in this area.
\end{abstract}

Keywords: Culture, performance, multinationals, social and cultural values. 
Oberföll, K., Camarena Adame, M.E. \& Saavedra García, M.L. (2018) Relationship between organizational culture and performance among German multinational companies in Mexico. Journal of Business, Universidad del Pacífico (Lima, Peru) Vol.10(2): 24-47

\section{Introduction}

Today, multinational corporations exist in unprecedented numbers. Besides their headquarters, these commercial and industrial firms have interests and plants established in several countries through which they internationalize their capital, organizational processes, and production by drawing on values, beliefs and procedures from these different locations.

Each country or region is defined by its own culture: a set of values, traditions, beliefs, habits, norms, attitudes and behaviors that give identity or belonging to its inhabitants. Being part of a culture entails certain behavioral traits that differ from those exhibited by members of other cultures (Schein, 2004), and this in turn affects the performance of the organizations operating within these cultures. In this context, the culture of German multinationals in Mexico - some 1,700 firms employing around 120,000 people - merits study.

Cultural diversity can, understandably, cause problems in interactions between persons who do not share national origins or nationalities; this is associated with differing behavior or problem-solving styles in response to certain work situations, or to adapting certain established work processes from one culture to another.

Just like nations and regions, organizations also develop a culture of their own that guides the attitudes and behaviors of their members through values, beliefs, and norms. Organizational culture is not dissimilar from local culture: In this regard, Connaughton and Shuffler (2007), based on a review of previous studies, demonstrate that national culture can affect organizational cultures and teamwork. To put it differently, each culture makes a mark on the organizations that develop within it. Thus, "the organizational cultures of culturally homogenous cultures incorporate common elements from a general culture, while in the case of culturally heterogenous countries, organizational cultures will present greater differences between one another" (Gómez \& Ricardo, 2012, p.26).

Along these lines, if an attempt is made to adapt a process from one culture to another, or if individuals from different national cultures are integrated in a single department, problematic situations could arise, potentially affecting the team's functioning and reducing the organization's performance (Gregory, Harris, Armenakes \& Shook, 2009). This happens because individuals behave in a way that is consistent with their values; thus, organizations have to create behavioral expectations that orientate employees to behave in a way that is consistent with the culture of the organization. In relation to this, Gregory, Harris, Armenakes and Shook (2009) point out that it is precisely this relationship between culture and behavior that provides the technical foundations on which to assert that culture affects performance.

However, heterogeneous teams can also resolve and overcome conflicts by developing a new organizational culture that proves highly effective, based on a collaborative approach to conflict management and decision-making (Connaughton \& Shuffler, 2007); firms with such teams are able to establish their own organizational culture that all members adopt, regardless of their own cultural origins.

However, these assumptions have largely been studied from a theoretical perspective thus far; this is particularly true in the case of multinational corporations, with their mixture of organizational factors, for which little empirical research has yet been done. Therefore, the aim of this study is to determine whether there is a relationship between organizational culture and performance among German multinationals operating in Mexico. 
Oberföll, K., Camarena Adame, M.E. \& Saavedra García, M.L. (2018) Relationship between organizational culture and performance among German multinational companies in Mexico. Journal of Business, Universidad del Pacífico (Lima, Peru) Vol.10(2): 24-47

This article contains three sections: I. Theoretical framework, subdivided as follows: German multinational corporations in Mexico, organizational culture and organizational performance; II. Method, where we present the research questions, hypothesis, delimitation of population and sample, variables and indicators, and measurement instruments; III. Analysis of the results, where we perform and interpret the descriptive and correlational analyses, and then present the conclusions, recommendations, limitations, and future lines of research.

\section{Theoretical framework}

\section{German multinational firms in Mexico}

At present, the economic relationship between Germany and Mexico is rather robust. Since 2011, Mexico has been Germany's second-largest trading partner in Latin America; in turn, Germany is Mexico's main trading partner in the European Union, accounting for more than a third of its trade with the grouping. These close links are bolstered by the presence of some 1,700 German-owned companies in Mexico, according to the Mexican-German Chamber of Commerce (CAMEXA). The accumulated capital of German companies in Mexico amounts to around US \$25 billion (Schindler, 2012); these firms employ 120,000 people, and generate $7 \%$ of Mexico's industrial output. Their productive activities are centered mainly on the automotive, pharmaceuticals, chemical, electrical and electronic, transport, and logistics industries (Schindler, 2012).

The automotive industry is crucial to both the German and Mexican economies; in Germany it characterizes the economic structure of various regions, and is responsible for almost 800,000 direct jobs and 1.8 million indirect jobs (Friedrich, 2010). Sales in the industry represent $20 \%$ of Germany's total across all industries, and make up $33 \%$ of the country's trade surplus.

Germany is regarded as the innovation hub for the global automotive industry (Germany Trade \& Invest, Automobil-Industrie); as such, large sums of money are allocated each year to research and development, where many jobs are concentrated.

In Mexico, the automotive industry generates 3.8 percent of the country's GDP (PWC, 2013), comprising $18 \%$ of all manufacturing and $23 \%$ of exports while employing 551,000 people directly and indirectly (Deutsch-Mexikanische Industrie- und Handelskammer, 2012). Indeed, given its manufacturing pedigree, low operating costs, the benefits of NAFTA, and its long industrial tradition, Mexico is a favorable base for the automotive industry (PWC, 2013).

\section{Organizational culture and performance}

There is no general consensus on the meaning of culture, with different authors defining it from the perspective of their particular approaches (Kroeber \& Kluckhohn, 1952; Allaire \& Firsirotu, 1984). For this study, we define it as the set of customs, beliefs, morals, laws, and ideas that are expressed in behavior, symbols, artifacts and lifestyle: in sum, a reflection of how society adapts to its environment. Culture may be learned or it may be passed down from generation to generation. 
Oberföll, K., Camarena Adame, M.E. \& Saavedra García, M.L. (2018) Relationship between organizational culture and performance among German multinational companies in Mexico. Journal of Business, Universidad del Pacífico (Lima, Peru) Vol.10(2): 24-47

Human relations theory gave rise to studies on organizational behavior, and this field has been broadened through focuses on organizational culture; according to Denison, Nieminen and Kotrba (2014), the first to use and describe the term "cultural organization" was Elliott Jaques in 1951, who regarded it as an informal social structure that explains the failure of formal policies.

Various different conceptualizations of organizational culture emerged thereafter (Geertz, 1973; Hofstede, 1980; Deal \& Kennedy, 1982; Smircich, 1983; Martin \& Siehl, 1983; Schein, 2004; Allaire \& Firsirotu, 1984; Cooke \& Rousseau, 1988, Denison, 1991; Gordon \& di Tomaso, 1992; Kotter \& Heskett, 1992; Cunha \& Cooper, 2002; Van Den Berg \& Wilderom, 2004; Hofstede \& Hofstede, 2005), but they all adhere to the notion of a system of ideas or patterns created and inherited within an organization, predisposing its members to a certain type of behavior.

Schein's (1984) model is one of the best known in studies of organizational culture. It is based on three levels: artifacts, beliefs and values, and basic assumptions. This model analyzes culture according to the degree to which it is visible to the observer. Artifacts are the visible products of a group and include language, technology, style, myths, and stories; or, in the case of an organization, structure, processes, and so on - that is, all that is easy to see but difficult to decipher. In turn, beliefs and values, as processes and ways of thinking and acting that have proven successful, draw heavily from artifacts. They are adopted by existing members, transmitted to new ones, and established as the organization's philosophy, serving as a behavioral guide in certain situations (Schein, 2004).

Based on a review of the literature, we have identified certain dimensions and variables used to measure organizational culture (Table 1).

Table 1 Dimensions and variables of organizational culture

\begin{tabular}{|c|c|c|}
\hline Variables & Definition & Indicators \\
\hline \multirow{8}{*}{$\begin{array}{l}\text { Hierarchy/Stru } \\
\text { cture }\end{array}$} & Cooke \& Rousseau (1988) & $\begin{array}{l}\text { Humanistic-helpful, affiliative, approval, conventional, } \\
\text { dependence, avoidance, oppositional, power, } \\
\text { competitive, competence/perfectionistic, } \\
\text { achievement, self-actualizing }\end{array}$ \\
\hline & Denison (1984) & Involvement \\
\hline & Van Den Berg \& Wilderom (2004) & $\begin{array}{l}\text { External orientation, interdepartmental coordination, } \\
\text { improvement orientation }\end{array}$ \\
\hline & Cameron \& Quinn (2011) & Hierarchy, clan, adhocracy, market \\
\hline & Hofstede (1980) & $\begin{array}{l}\text { Parochial vs. professional, open system vs. closed system, loose } \\
\text { control vs. tight control, pragmatic vs. normative }\end{array}$ \\
\hline & $\begin{array}{l}\text { Ginevicius \& } \\
\text { Vaitkunaite } \\
\text { (2006) }\end{array}$ & $\begin{array}{l}\text { Involvement, transmission of information, strategic } \\
\text { direction, communication, coordination and } \\
\text { integration }\end{array}$ \\
\hline & Harrison (1972) & Organizational orientation, person orientation, market \\
\hline & Hofstede (1980) & $\begin{array}{l}\text { Power distance, individualism vs. collectivism, uncertainty } \\
\text { avoidance, masculinity vs. femininity (long-term vs. short-term } \\
\text { orientation) }\end{array}$ \\
\hline
\end{tabular}


Oberföll, K., Camarena Adame, M.E. \& Saavedra García, M.L. (2018) Relationship between organizational culture and performance among German multinational companies in Mexico. Journal of Business, Universidad del Pacífico (Lima, Peru) Vol.10(2): 24-47

\begin{tabular}{|c|c|c|}
\hline & Deal \& Kennedy (1982) & $\begin{array}{l}\text { Tough guy/macho, work hard/play hard, bet your company, } \\
\text { process }\end{array}$ \\
\hline \multirow[t]{4}{*}{ Values } & Denison (1991) & Mission, adaptability, consistency \\
\hline & Cameron \& Quinn (2011) & Hierarchy, clan, adhocracy, market \\
\hline & Cunha \& Cooper (2002) & $\begin{array}{l}\text { Organizational orientation, performance orientation, } \\
\text { people orientation, market orientation }\end{array}$ \\
\hline & Van Den Berg \& Wilderom (2004) & Autonomy, human resources \\
\hline \multirow[t]{2}{*}{$\begin{array}{l}\text { Human } \\
\text { resources }\end{array}$} & Hofstede (1980) & $\begin{array}{l}\text { Process-oriented vs. results-oriented, employee-oriented vs job- } \\
\text { oriented }\end{array}$ \\
\hline & $\begin{array}{l}\text { Ginevicius \& } \\
\text { Vaitkunaite } \\
\text { (2006) }\end{array}$ & $\begin{array}{l}\text { Cooperation, learning, care about clients, adaptability, reward } \\
\text { and incentive system, agreement }\end{array}$ \\
\hline
\end{tabular}

Source: Compiled by authors based on the authors cited.

In the view of Hamann, Schiemann, Bellora and Guenther (2013), the aim of organizational performance ought to be organizational effectiveness In this regard, Strasser et al. (quoted by Hamann et al., 2013), note that organizational effectiveness is "the degree to which organizations are attaining all the purposes they are supposed to" (p.70). Hamann et al. (2013) distinguish between two types of performance - operational and organizational - while they see operational performance as "the fulfillment of operational goals within different value chain activities" (p.71). For their definition of organizational performance, they quote Combs et al. in reference to "the economic outcomes resulting from the interplay among an organization's attributes, actions, and environment" (p.70).

Denison (1991), was one of the first authors to develop a model of organizational culture in different contexts, attempting to quantify organizational culture by relating it to performance. This model takes into account the four features of organizational culture: mission, participation, adaptability, and consistency, relating them to variables of performance and confirming the relationship between organizational culture and performance (profitability, sales growth, market share, innovation, quality of products and services, and employee satisfaction).

Many researchers have attempted to validate Denison's model. These include Gómez and Ricardo (2012), who establish a direct, positive relationship between culture and innovation; Mobley, Wang and Fang (2005), who, on the basis of this relationship, propose profiles of different companies; and Nazir and Lone (2008), who study employees of firms in the cement, textile, and steel industries, obtaining the same results as Denison.

However, there are other studies in which the model is less effective; for instance, Martínez (2010) do not obtain strong affirmations about the model's discriminative validity in relation to the firms studied.

Other works are able to relate organizational culture with performance; Franke, Hofstede and Bond (1991) conduct a comparative study to determine why certain countries develop competitive advantages while others do not, finding there to be a significant relationship between the dimensions of organizational culture (power distance, 
Oberföll, K., Camarena Adame, M.E. \& Saavedra García, M.L. (2018) Relationship between organizational culture and performance among German multinational companies in Mexico. Journal of Business, Universidad del Pacífico (Lima, Peru) Vol.10(2): 24-47

individualism, masculinity, uncertainty avoidance, Confucian dynamism, integration, human values, and moral discipline) and a country's growth rate.

For their part, Gálvez and García (2011) empirically validate the relationship between different types of organizational culture (clan, adhocracy, hierarchy, market, and innovation) and performance systems (internal processes, open systems, rational, human relations).

Table 2 presents a broader overview of past studies, most of which are based on the contributions of Hofstede, Denison, or Cameron and Quinn. We adapt these indicators to the present study and relate them to performance, financial, and operational measures.

Table 2 Research on the relationship between culture and performance

\begin{tabular}{|c|c|c|c|}
\hline Author & Objective & Variables & Findings \\
\hline Denison (1991) & $\begin{array}{l}\text { Establish the relationship } \\
\text { between organizational culture } \\
(\mathrm{OC}) \text { and performance }\end{array}$ & $\begin{array}{l}\text { Four dimensions of } \mathrm{OC} \\
\text { Financial indicators }\end{array}$ & $\begin{array}{l}\text { A relationship does } \\
\text { exist }\end{array}$ \\
\hline $\begin{array}{l}\text { Calori \& Sarnin } \\
(1991)\end{array}$ & $\begin{array}{l}\text { Propose a hypothesis on the } \\
\text { relationship between } O C \text { and } \\
\text { organizational performance } \\
\text { (OP) }\end{array}$ & $\begin{array}{l}\text { Twelve dimensions of OC } \\
\text { Financial indicators }\end{array}$ & $\begin{array}{l}\text { Relationships } \\
\text { established in the case } \\
\text { some dimensions }\end{array}$ \\
\hline $\begin{array}{l}\text { Franke, Hofstede } \\
\text { \& Bond (1991) }\end{array}$ & $\begin{array}{l}\text { Identify cultural factors that } \\
\text { appear to be the root of } \\
\text { economic development }\end{array}$ & $\begin{array}{l}\text { Hofstede's five dimensions } \\
\text { GDP per capita, growth rate }\end{array}$ & $\begin{array}{l}\text { Relationship between } \\
\text { GDP per capita and } \\
\text { certain dimensions } \\
\text { Relationship between } \\
\text { all dimensions and the } \\
\text { growth rate }\end{array}$ \\
\hline $\begin{array}{l}\text { Gordon \& Di } \\
\text { Tomaso (1992) }\end{array}$ & $\begin{array}{c}\text { Investigate the relationship } \\
\text { between the strength of } \mathrm{OC} \text { and } \\
\text { OP }\end{array}$ & $\begin{array}{l}\text { Six dimensions of OC } \\
\text { Asset growth }\end{array}$ & $\begin{array}{l}\text { A relationship does } \\
\text { exist }\end{array}$ \\
\hline $\begin{array}{l}\text { Marculides \& } \\
\text { Heck (1993) }\end{array}$ & $\begin{array}{l}\text { Draw up a relationship map } \\
\text { between OC and OP }\end{array}$ & $\begin{array}{l}\text { Five dimensions of } \mathrm{OC} \\
\text { Financial indicators }\end{array}$ & $\begin{array}{l}\text { A relationship does } \\
\text { exist } \\
\text { Strong relationship } \\
\text { between task } \\
\text { organization and } \\
\text { performance }\end{array}$ \\
\hline $\begin{array}{l}\text { Chow, Haddad \& } \\
\text { Wu (2002) }\end{array}$ & $\begin{array}{l}\text { Relationship between } \mathrm{OC} \text { and } \\
\text { OP in non-western settings }\end{array}$ & $\begin{array}{l}\text { Eight dimensions of } \mathrm{OC} \\
\text { Financial indicators }\end{array}$ & $\begin{array}{l}\text { A relationship does } \\
\text { exist }\end{array}$ \\
\hline $\begin{array}{l}\text { Ogaad, Larsen \& } \\
\text { Marnburg } \\
(2005)\end{array}$ & $\begin{array}{l}\text { Relationship between } \mathrm{OC} \text { and } \\
\text { the performance of managers in } \\
\text { the restaurant industry }\end{array}$ & $\begin{array}{c}\text { Four dimensions of OC } \\
\text { Efficacy, cleaning, additional } \\
\text { sales, personnel cost, profit } \\
\text { margin }\end{array}$ & $\begin{array}{l}\text { No relationship exists } \\
\text { between OC and OP }\end{array}$ \\
\hline $\begin{array}{l}\text { Winston \& } \\
\text { Dadzie (2007) }\end{array}$ & $\begin{array}{c}\text { Determine the relationship } \\
\text { between the dimensions of OC } \\
\text { and OP }\end{array}$ & $\begin{array}{l}\text { Four dimensions of OC } \\
\text { Profit margin, growth and } \\
\text { market share }\end{array}$ & $\begin{array}{l}\text { Relationship between } \\
\text { hierarchy and sales } \\
\text { growth }\end{array}$ \\
\hline $\begin{array}{l}\text { Gálvez \& García } \\
\text { (2011) }\end{array}$ & $\begin{array}{l}\text { Verify the relationship between } \\
\text { OC and company performance }\end{array}$ & $\begin{array}{c}\text { Five types of OC } \\
\text { Five performance systems }\end{array}$ & $\begin{array}{l}\text { Partial relationships } \\
\text { found }\end{array}$ \\
\hline
\end{tabular}




\begin{tabular}{|c|c|c|c|}
\hline $\begin{array}{l}\text { Sai On Cheung, } \\
\text { Wong \& Lam } \\
(2012)\end{array}$ & $\begin{array}{c}\text { Establish the relationship } \\
\text { between the dimensions of OC } \\
\text { and OP }\end{array}$ & $\begin{array}{c}\text { Eight dimensions of OC } \\
\text { Financial indicators, internal } \\
\text { processes, customers, } \\
\text { innovation and learning }\end{array}$ & $\begin{array}{l}\text { A significant } \\
\text { relationship exists } \\
\text { between } O C \text { and OP }\end{array}$ \\
\hline $\begin{array}{l}\text { Jacobs, } \\
\text { Mannion, } \\
\text { Davies, Harrison, } \\
\text { Konteh \& } \\
\text { Walshe (2013) }\end{array}$ & $\begin{array}{l}\text { Examine the relationship } \\
\text { between the culture of high } \\
\text { performance and the hospital } \\
\text { star ratings system }\end{array}$ & $\begin{array}{c}\text { Four types of OC } \\
\text { Star system }\end{array}$ & $\begin{array}{c}\text { A positive relationship } \\
\text { exists }\end{array}$ \\
\hline $\begin{array}{l}\text { Yesil \& Kaya } \\
(2013)\end{array}$ & $\begin{array}{l}\text { Investigate the relationship } \\
\text { between } O C \text { and financial } \\
\text { performance }\end{array}$ & $\begin{array}{l}\text { Four types of financial } \\
\text { indicators }\end{array}$ & $\begin{array}{l}\text { No relationship was } \\
\text { found }\end{array}$ \\
\hline Ozigbo (2013) & $\begin{array}{l}\text { Explore the relationship } \\
\text { between } O C \text { and OP }\end{array}$ & $\begin{array}{l}\text { Four dimensions of OC } \\
\text { Financial indicators }\end{array}$ & $\begin{array}{c}\text { A positive relationship } \\
\text { exists }\end{array}$ \\
\hline $\begin{array}{l}\text { Wei, Samiee \& } \\
\text { Lee }(2014)\end{array}$ & $\begin{array}{l}\text { Establish the relationship } \\
\text { between OC types and OP } \\
\text { indicators }\end{array}$ & $\begin{array}{c}\text { Two types of OC } \\
\text { Market, product and financial } \\
\text { indicators }\end{array}$ & $\begin{array}{l}\text { Partial relationships } \\
\text { found }\end{array}$ \\
\hline $\begin{array}{l}\text { Boyce, } \\
\text { Nieminen, } \\
\text { Gillespie, Ryan \& } \\
\text { Denison (2015) }\end{array}$ & $\begin{array}{l}\text { Study the longitudinal } \\
\text { relationships between OC and } \\
\text { OP }\end{array}$ & $\begin{array}{c}\text { Four dimensions of } \mathrm{OC} \\
\text { Customer satisfaction, sales }\end{array}$ & $\begin{array}{c}\text { Significant relationships } \\
\text { found }\end{array}$ \\
\hline $\begin{array}{l}\text { Naranjo, } \\
\text { Jiménez \& Sanz } \\
(2016)\end{array}$ & $\begin{array}{l}\text { Study the role of organizational } \\
\text { culture as a factor that can } \\
\text { stimulate or restrain innovation, } \\
\text { and can thus affect the } \\
\text { performance of firms }\end{array}$ & $\begin{array}{l}\text { Adhocracy, clan, market, and } \\
\text { hierarchy } \\
\text { Innovation indicators }\end{array}$ & $\begin{array}{l}\text { Significant positive } \\
\text { relationships found }\end{array}$ \\
\hline Leithy (2017) & $\begin{array}{l}\text { Develop and prove a theoretical } \\
\text { framework that combines OC } \\
\text { and OP as dependent variables. }\end{array}$ & $\begin{array}{l}\text { Job satisfaction, organization } \\
\text { commitment } \\
\text { Financial performance }\end{array}$ & No relationship exists \\
\hline $\begin{array}{l}\text { Langat \& Lagat } \\
(2017)\end{array}$ & $\begin{array}{l}\text { Establish whether a relationship } \\
\text { exists between organizational } \\
\text { culture and performance }\end{array}$ & $\begin{array}{l}\text { Culture of participation } \\
\text { Employee performance }\end{array}$ & $\begin{array}{l}\text { A significant positive } \\
\text { relationship exists }\end{array}$ \\
\hline
\end{tabular}

Source: Compiled by authors based on the authors cited.

Based on these studies, the variables of organizational culture can be grouped into: hierarchy/structure, values, and human resources. We include all of these variables in this study, and especially the indicators of hierarchy, orientation, internal functioning, values, and employees.

Thus, organizational performance is a combination of financial performance with indicators such as financial ratios, sales, costs; and of operational performance with indicators such as respect for employees, products, and customers.

We prepared a questionnaire based on Hofstede's $(1980,2001)$ indicators of culture (power distance, individualism vs. collectivism, uncertainty avoidance, masculinity vs. femininity, long-term vs. short-term orientation) for the values; the indicators of Cameron and Quinn (2011) hierarchy, clan, adhocracy, market) for the variables of structure and hierarchy; and Denison's (1991) variables of operational performance (innovation, market share, quality, employee satisfaction). 
Oberföll, K., Camarena Adame, M.E. \& Saavedra García, M.L. (2018) Relationship between organizational culture and performance among German multinational companies in Mexico. Journal of Business, Universidad del Pacífico (Lima, Peru) Vol.10(2): 24-47

\section{Method}

This is a qualitative study, since the values on which the data are based are predominantly qualitative. We collected the data through personal interviews and a questionnaire. The study is cross-sectional, in that we analyzed the organizational culture of each of the selected firms on a single occasion. Our approach is also correlational, as we establish the influence of organizational culture on performance. We collected the data through a direct structured questionnaire applied personally to five company directors and to 232 employees to one of these firms.

\section{Research questions}

To understand culture and performance within organizations and establish a relationship on the basis of the variables, we formulated the question: is there a significant relationship between organizational culture and performance within German multinational corporations in Mexico?

On the one hand, we sought to ascertain the nationalities of the employees at the selected subsidiaries, as well as the values, beliefs, habits, and behaviors that exist within these firms. This prompted another question: are there any conflicts between employees as a result of differing values, beliefs, or behaviors? How are or were such conflicts addressed? What are or were the consequences of these conflicts?

Moreover, we were interested in finding out how the firms measure their performance: whether they have their own metrics or model, and whether these can be related to the indicators we use in this study. To this end, we posed another two questions: What aims do the firms pursue in terms of performance? And, what is their current performance status?

\section{Research hypothesis}

The studies conducted by Denison (1991); Gordon and Di Tomaso (1992); Marculides and Heck (1993); Franke, Hofstede and Bond (1999); Chow, Haddad and Wu (2002); Ogaad, Larsen and Marnburg (2005); Winston and Dadzie (2007); Gálvez and García (2011); Jacobs, Mannion, Davies, Harrison, Konteh and Walshe (2013); Ozigbo (2013); and Boyce, Nieminen, Gillespie, Ryan and Denison (2015) find that there is a significant relationship between culture and organizational performance, even when different indicators are used to measure both variables.

$\mathrm{H}_{1}$ : There is a significant relationship between organizational culture and performance.

Eighty-one percent of autoparts firms operating in Mexico have majority foreign ownership, while the remaining $19 \%$ are Mexican-owned. German multinationals tend to prefer foreign executives (ProMexico, 2013; PWC, 2013) which leads us to our second hypothesis.

$\mathrm{H}_{2}$ : Individuals of different nationalities work for German multinational corporations.

According to PWC (2013), there are several reasons why German multinationals opt to establish themselves in Mexico, not least the low production costs, openness to markets, proximity to interdependent companies in the same group, and the widespread adoption 
Oberföll, K., Camarena Adame, M.E. \& Saavedra García, M.L. (2018) Relationship between organizational culture and performance among German multinational companies in Mexico. Journal of Business, Universidad del Pacífico (Lima, Peru) Vol.10(2): 24-47

of just-in-time deliveries. Mexican production processes are closely linked to those in Germany. The firms favor Mexican workers because of their high level of training acquired from previous work at German multinationals, while German executives enrich their interpersonal skills through their interactions with local employees (ProMexico, 2013).

$\mathrm{H}_{3}$ : The organizational culture of the multinational corporations is influenced by both German and Mexican culture.

Connaughton and Shuffer (2007) argue that national culture can affect organizational culture and make teamwork difficult, while Gómez and Ricardo (2012) propose that the more heterogeneous the culture between two countries, the greater the difference between the organizational cultures; thus, when two individuals from different cultures are incorporated in a department, conflicts may be expected to arise (Gregory, Harris, Armenakes \& Shook, 2009).

\section{$\mathrm{H}_{4}$ : There are conflicts that are caused by cultural differences}

Schein $(1984,2004)$, refers to cultural dimensions as artifacts; that is, visible aspects of a culture, of which the structure of an organization is one example. In turn, Cooke and Rousseau (1988), Denison (1984), Van Den Berg and Wilderom (2004), Cameron and Quinn (2011), Hofstede (1980), and Ginevicius and Vaitkunaite (2006) argue that empirical studies prove structure to be a dimension of organizational culture, and that it has an influence on organizational culture.

$\mathrm{H}_{5}$ : The structure of an organization influences its performance

Gordon and Di Tomaso (1992), and Ogaad, Larsen and Mamburg (2005), find that values influence organizational performance as a consequence of people's behavior. It is important that the organization create an expectation that employees behave in a certain desired way.

$\mathrm{H}_{6}:$ The cultural values of an organization influences its performance

Cheung, Wong and Lam (2012) refer to conflict resolution as a dimension of organizational culture, and verify its relationship with organizational performance. Meanwhile, Connaughton and Shuffler (2007) argue that conflicts can be resolved with the collaboration of employees.

$\mathrm{H}_{7}$ : The way in which conflicts are resolved and the outcomes of conflicts influences performance

\section{Delimitation of population and sample}

Our target population was made up of German multinational corporations in Mexico. There are currently around 1,700 German-owned firms operating in Mexico, distributed across different economic sectors. We delimited the population to the automobile components industry, given its level of development in both Germany and Mexico. 
Oberföll, K., Camarena Adame, M.E. \& Saavedra García, M.L. (2018) Relationship between organizational culture and performance among German multinational companies in Mexico. Journal of Business, Universidad del Pacífico (Lima, Peru) Vol.10(2): 24-47

We chose the multiple case study option for our sample, analyzing five cases of firms that produce autoparts and automobile components. Although we based our selection on the firms' availability and willingness to grant access, all of them were based in the southeast of Mexico. In the case of Firm E, we applied the questionnaire to a larger, stratified sample of employees - 232 in total - at the request of the management.

\section{Variables and indicators}

Having identified the dimensions and variables shown in Table 1, we concluded that the variables that describe organizational culture are Structure, Values, and Conflict Resolution.

In turn, we measured structure by way of the following indicators: Orientation, Hierarchy, Leadership Style, Information Flow. Moreover, we measured values by way of: Power Distance, Individualism vs. Collectivism, Uncertainty Avoidance, Masculinity vs. Femininity, and Short-term vs. Long-term Orientation. To measure conflict resolution, we used Conflict Type, Conflict Frequency, and Conflict Resolution as indicators.

For their part, the variables of organizational performance are Financial Performance and Operational Performance. We decided to measure financial performance by way of the indicators Return on Assets (financial ratio), Sales, and Growth, since these are the most frequently used in the literature. For Operational Performance, we chose the indicators of Denison (1991) and Denison, Janovics and Young (2005): innovation, Product and Service Quality, Market Share, Quality of Goods and Services, and Employee Satisfaction, again because they coincide with the indicators obtained.

\section{Measurement instrument}

Our instrument was a 60-question questionnaire based on the literature review, which we used to obtain a profile of the firms' organizational culture and performance (see Table 3).

We applied this questionnaire to five firms through interviews with experts in the fields of production, human resources, and administration, which gave us an initial introduction to the organizational culture and performance of the firms.

Table 3 Description of the measurement instrument

\begin{tabular}{|c|c|c|}
\hline Variables & Indicators & Items/Questions \\
\hline \multirow{5}{*}{$\begin{array}{l}\text { Structure and } \\
\text { Hierarchy }\end{array}$} & $\begin{array}{l}\text { Orientation towards external or } \\
\text { internal factors }\end{array}$ & Internal factors, external factors (p. 1, 2). \\
\hline & Hierarchy & $\begin{array}{c}\text { Organizational structure, type of } \\
\text { hierarchy }(p .3,4) .\end{array}$ \\
\hline & Leadership style & $\begin{array}{l}\text { Type of leadership, objective, authority, } \\
\text { delegation, control, integration, freedom } \\
\text { (p. 5-11). }\end{array}$ \\
\hline & Information flow & $\begin{array}{l}\text { Transmission, direction, communication, } \\
\text { coordination (p. 12-15). }\end{array}$ \\
\hline & Power distance & $\begin{array}{c}\text { Decision-making style, closeness to } \\
\text { employees (p. 16, 17). }\end{array}$ \\
\hline
\end{tabular}


Oberföll, K., Camarena Adame, M.E. \& Saavedra García, M.L. (2018) Relationship between organizational culture and performance among German multinational companies in Mexico. Journal of Business, Universidad del Pacífico (Lima, Peru) Vol.10(2): 24-47

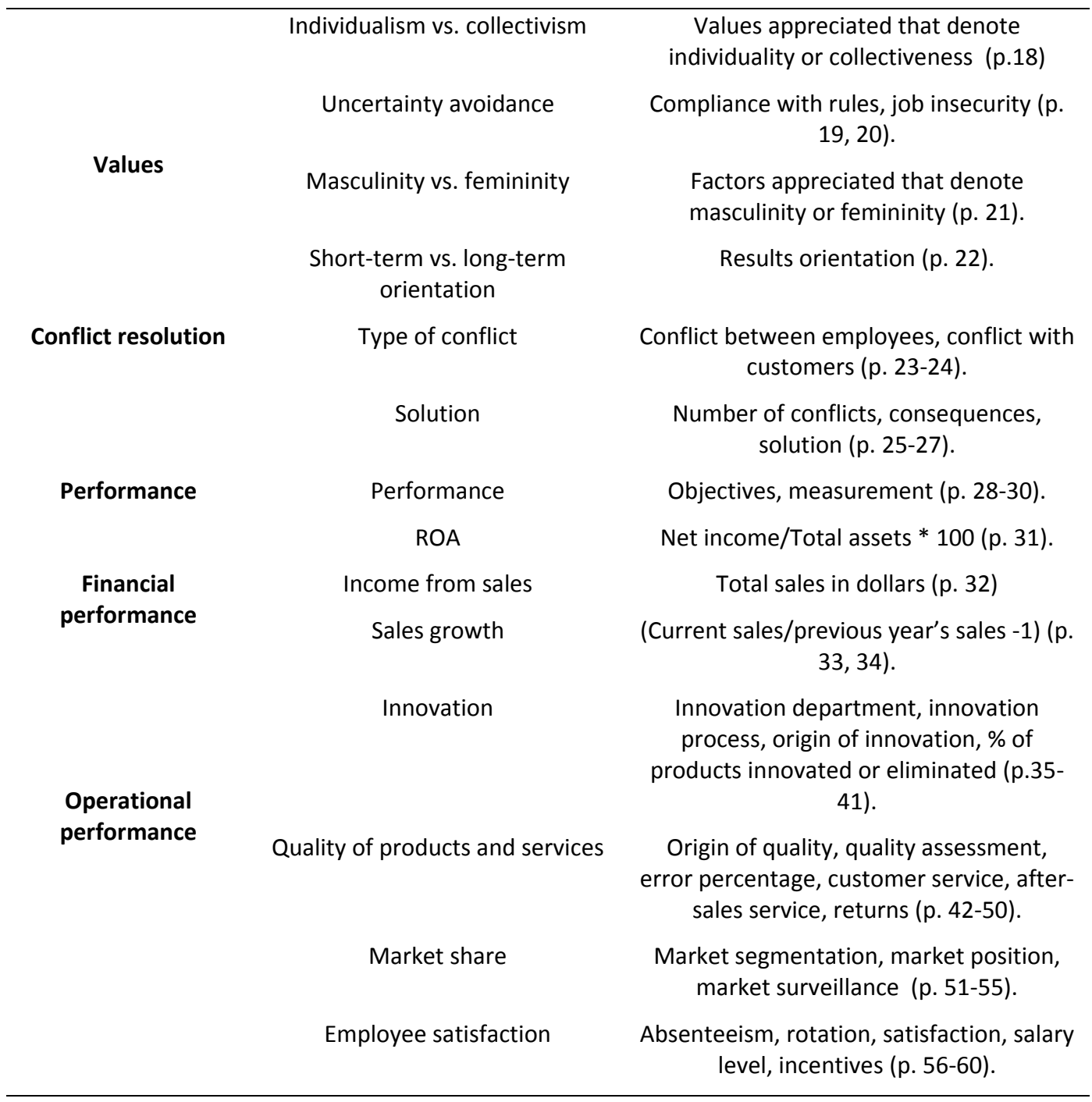

\section{Analysis of results}

First, we interviewed one of the managers of each firm. Then, we applied the questionnaire described in Section 2.5 to the 232 employees of Firm E.

We conducted a descriptive and correlational analysis using the chi-squared test and Spearman's correlation, with a confidence level of $95 \%$ and an alpha error of $5 \%$. Using the results of these analyses, we prepared crosstab tables and graphs to facilitate interpretation of the findings.

\section{Description of the firms}

Four of the firms were large (+250 employees): Firm A (193 + across several plants), Firm C (450), Firm D (210 + across several plants), and Firm E (778). Firm B was the only medium-sized one (60 employees). It should be noted that firms A, B, C, and E are tier 1 suppliers, while Firm D is tier 2 and is soon to become tier 1. Each firm is distinctive because of the product they sell, the market segment they supply, or their main customer. 
Oberföll, K., Camarena Adame, M.E. \& Saavedra García, M.L. (2018) Relationship between organizational culture and performance among German multinational companies in Mexico. Journal of Business, Universidad del Pacífico (Lima, Peru) Vol.10(2): 24-47

Firm $\mathrm{E}$ has an advantageous position in the market, covering $80 \%$ of the demand of its main customer, an assembly firm, but also supplies to other firms in smaller quantities. Its product is low-volume, considered to be artisanal, and aimed at a premium market segment. Ninety percent of its output is exported to the United States, where it has a large market.

These firms have been well established in the Mexican market for more than 12 years, having started operations there because production and labor costs are lower than in Germany or the United States. Their presence also allows them to provide a faster supply and a closer service to the large assemblers operating in Mexico or the United States, enabling reduced times as well as operating and logistics costs.

\section{The organizational culture of multinational firms}

\section{Structure and hierarchy}

Of the twelve interviewees, only three, or $25 \%$, were women. This implies that males predominate in the management positions of these companies.

As to the nationality of the employees, the five firms primarily employ Mexicans, in addition to a minority of foreign nationals (largely Germans, Americans, or Brazilians). This shows that a mix of nationalities is not particularly general, which disproves $\mathrm{H} 2$ that individuals of different nationalities work together at the firms.

Many of the processes applied come from Germany and are adapted in Mexico. It is also notable that all interviews refer to a certain dependence on the parent company in Germany due to a vertical structure (in a range of $1=$ very vertical and $5=$ very horizontal, the median is 2 ) and a somewhat centralized hierarchy (in a range of $1=$ very centralized and $5=$ very decentralized, the median is 2 ).

However, the companies display different forms of organizational structure. A, B, and C utilize functional or product-based divisions, while $D$ is structured around international divisions, with most products exported, and E has geographical divisions.

As to leadership style, there is a tendency for decision-making to be centered on the boss (the median is 3 on a scale of $1=$ boss and $5=$ team), with some team contributions (median of 3, where 1=boss, 5=own knowledge) and moderate employee decisionmaking freedom (median of 3.5, where $1=$ low and $5=$ high freedom). Although a high degree of process planning and control is noted (the median is 2.25 , where 1=high control and $5=$ high flexibility), more importance is still placed on results than on process (even though the median is 3 on a scale of $1=$ result and $5=$ process).

However, there are differences between the firms: $A$ and $C$ are led by a highly centralizing boss and $B, D$ and $E$ by a boss more open to receiving suggestions, while $D$ also has much more flexibility in its processes than the other four. Finally, A, C, D and E are more result-oriented, while $B$ is more process-oriented.

Although firms A, B and D use SAP as an information system, the departments only have access to information that corresponds to them; Firm $E$ has a different system than SAP, and the information is shared either with all departments or just the corresponding ones; for its part, Firm $C$ has no information system, and the information is only shared with the individuals directly involved. Each of the firms admit to difficulties caused by the receipt of delayed or incomplete information; while at Firm $D$ conflicts arise from information not arriving on time or to the right person. 
Oberföll, K., Camarena Adame, M.E. \& Saavedra García, M.L. (2018) Relationship between organizational culture and performance among German multinational companies in Mexico. Journal of Business, Universidad del Pacífico (Lima, Peru) Vol.10(2): 24-47

\section{Values}

Table 4 presents a comparison of the firms' position in relation to the values, based on Hofstede (1980). It is notable that they all have very different profiles than one another, while Firm $\mathrm{E}$ stands out for having an intermediate profile in each category.

Table 4 Comparison of values in firms

\begin{tabular}{ccc}
\hline & Power distance & \\
\hline Small & Medium & Large \\
B / Germany & $\mathrm{C} / \mathrm{E}$ & $\mathrm{A} / \mathrm{D} /$ Mexico \\
\hline & Individualism versus collectivism & \\
\hline Individualism & $\mathrm{A} / \mathrm{E}$ & Collectivism \\
B / Germany & Masculinity versus femininity & $\mathrm{C} / \mathrm{D} /$ Mexico \\
\hline Masculinity & $\mathrm{D} / \mathrm{E}$ & Femininity \\
\hline B / C / Mexico / Germany & Uncertainty avoidance & $\mathrm{A}$ \\
\hline Low & Medium & Long \\
& C / D / E / Germany & $\mathrm{A} / \mathrm{B} /$ Mexico \\
\hline & Short-term versus long-term orientation & \\
\hline Short & Medium & Long \\
A / C / D & & B
\end{tabular}

According to these results the firms tend towards collectivism, just like Mexican society as a whole in Hofstede and Hofstede (2005). Firms B, C, D and E tend towards masculinity, as prior studies have found German and Mexican society to do. In this work, all firms tend to avoid unknown situations. This can be seen in their dependence on the parent company, and the standard processes and rules it imposes. A, C and D take more of a short-term approach to work, which could mean that they still operate more like a family company. The managers believe that a firm of the size of $E$ should not be so paternalistic, because this hampers development. It can be seen clearly that the firms possess some values considered as salient in Mexico, and others so regarded in Germany; this proves hypothesis $\mathbf{H}_{\mathbf{3}}$, that organizational culture is influenced by both Mexican and German culture.

\section{Conflict resolution}

Hypothesis $\mathbf{H}_{4}$ holds that conflicts are caused by workplace interaction between individuals from different cultures. The interviewees point to certain cultural differences related to "German punctuality", "the rigid processes from Germany", Mexican flexibility and improvisation", and "the indiscipline of the Mexicans", etc. - that is, they are aware of certain differences, but are used to them given their frequent dealings. They do not mention problematic situations or conflicts resulting from different habits or ways of thinking or acting by individuals from other cultures, probably because the numbers of foreign employees are minimal. Thus, $\mathbf{H}_{\mathbf{4}}$, that conflicts are caused by individuals with different national cultures, does not hold true.

The internal conflicts that do occur more frequently are associated with the firms' daily operations: Firm A mentions problems related to internal communication of unspecified objectives; Firm B faces problematic situations caused by information delays and 
Oberföll, K., Camarena Adame, M.E. \& Saavedra García, M.L. (2018) Relationship between organizational culture and performance among German multinational companies in Mexico. Journal of Business, Universidad del Pacífico (Lima, Peru) Vol.10(2): 24-47

differences between team members; similarly, Firm $C$ suffers from information failures and, occasionally, a lack of cooperation between employees; firm D points to other issues, such as differing senses of urgency from one department to another, lack of demarcation of responsibilities or operating levels, and inter-personal problems related to gossip or competition in pursuit of recognition; finally, Firm E, as well as problems of communication, information, and cooperation, cites abuse of authority, abuse of bonuses, bribery of the supervisor, and unpunctuality as sources of conflict.

Across the four companies, these problems all lead to the same general consequences: delays in the production process. There would appear to be more conflicts in firms $D$ and $\mathrm{E}$, leading to feelings of frustration among the employees. No serious problems were reported in relation to customers, though there are some disputes around supplier failings, non-compliance with delivery times, or lack of follow-up of customer needs. However, in general, conflicts are resolved directly, without impacting business relations or causing a loss of customers.

\section{Performance indicators within the firms}

Employee performance is measured on a daily basis. Moreover, the firms have a department for product improvement and operators are always notified of any design changes.

Financial and operational performance

Table 5 provides a comparison of the firms' performance levels. It is notable that none of the four firms share their financial information in detail with their bosses, with this information handled internally by the financial departments. As to ROA, income, growth, and so on, only the managers of Firm E seem to be better informed. In the absence of such information, any comparisons of financial performance would be inconclusive.

Table 5 Indicators of financial and operational performance

\begin{tabular}{cccccc}
\hline Indicator & Firm A & Firm B & Firm C & Firm D & Firm E \\
\hline ROA & - & - & - & $14 \%$ & - \\
Income/sales & $>250$ & $4-100$ & $>250$ & $>250(800)$ & $>250$ \\
Mill. pesos) & & & & & $(1500)$ \\
Growth & $5 \%$ & - & $30 \%$ & Little over $0 \%$ & $40 \%$ \\
Errors & $<1 \%$ & $1-2 \%$ & $2-3 \%$ & $0.2-0.5 \%$ & $0.5-2 \%$ \\
Complaints & 3 per month & 1 per month & $0-20 \%$ & $5 \%$ & $0.5 \%$ \\
Returns & 0 & 0 & $<1 \%$ & $1-5 \%$ & $0.5 \%$ \\
Share & $80 \%$ & $50 \%$ & $80 \%$ & $60 \%$ & $18 \%(80 \%)$ \\
Absenteeism & $3 \%$ & $1 \%$ & $<5 \%$ & $2 / 20 \%$ & $<2 \%$ \\
Turnover & 1 & $1 / 3$ & 1 & $1 / 3$ & 1 \\
\hline & & & & &
\end{tabular}

Most firms did not provide information about return on assets (ROA), information on sales is not very detailed, and information on growth is very varied, so it is difficult to make comparisons.

On the other hand, highly detailed information on operational performance is available, and shows that the error percentage in the production or service is very low across all firms: the lowest is Firm D, at $0.2 \%$, while the highest is Firm C, at between 2 and 3\%. 
Oberföll, K., Camarena Adame, M.E. \& Saavedra García, M.L. (2018) Relationship between organizational culture and performance among German multinational companies in Mexico. Journal of Business, Universidad del Pacífico (Lima, Peru) Vol.10(2): 24-47

Meanwhile, complaints are minimal in these firms, and do not exceed $5 \%$. In the case of market share, differences do exist: firms $A$ and $C$ both state that they supply around $80 \%$ of the market, while firms $\mathrm{B}, \mathrm{C}$, and $\mathrm{E}$ reach $50 \%, 60 \%$, and $18 \%$, respectively.

Finally, in the category of employee satisfaction, firms A, B, C, and E record absenteeism rates of more than $5 \%$, while $D$ points to a rate of $2 \%$ among those in administrative posts and of $20 \%$ for operators.

Staff turnover is low; however, in Firm B, there is a high turnover of outsourced contractors, while Firm D has a high turnover among its operators. Thus, one's position (and hence employment situation) influences satisfaction.

\section{Relationship between organizational culture and performance}

In our analysis, we found no relationships between the initial variables of culture (Structure, Values, and Conflict Resolution) and performance (Financial Performance, Innovation, Market Share, Quality, and Employee Satisfaction). We did, however, find relationships between isolated indicators (See Graph 1). This leads us to reject hypothesis $\mathbf{H}_{\mathbf{5}}$, which states that structure influences performance; hypothesis $\mathbf{H}_{\mathbf{6}}$, which assumes that the values influence performance; and hypothesis $\mathbf{H}_{7}$, which proposes that the way of resolving conflicts influences performance.

\section{Graph 1. Relationships between indicators}

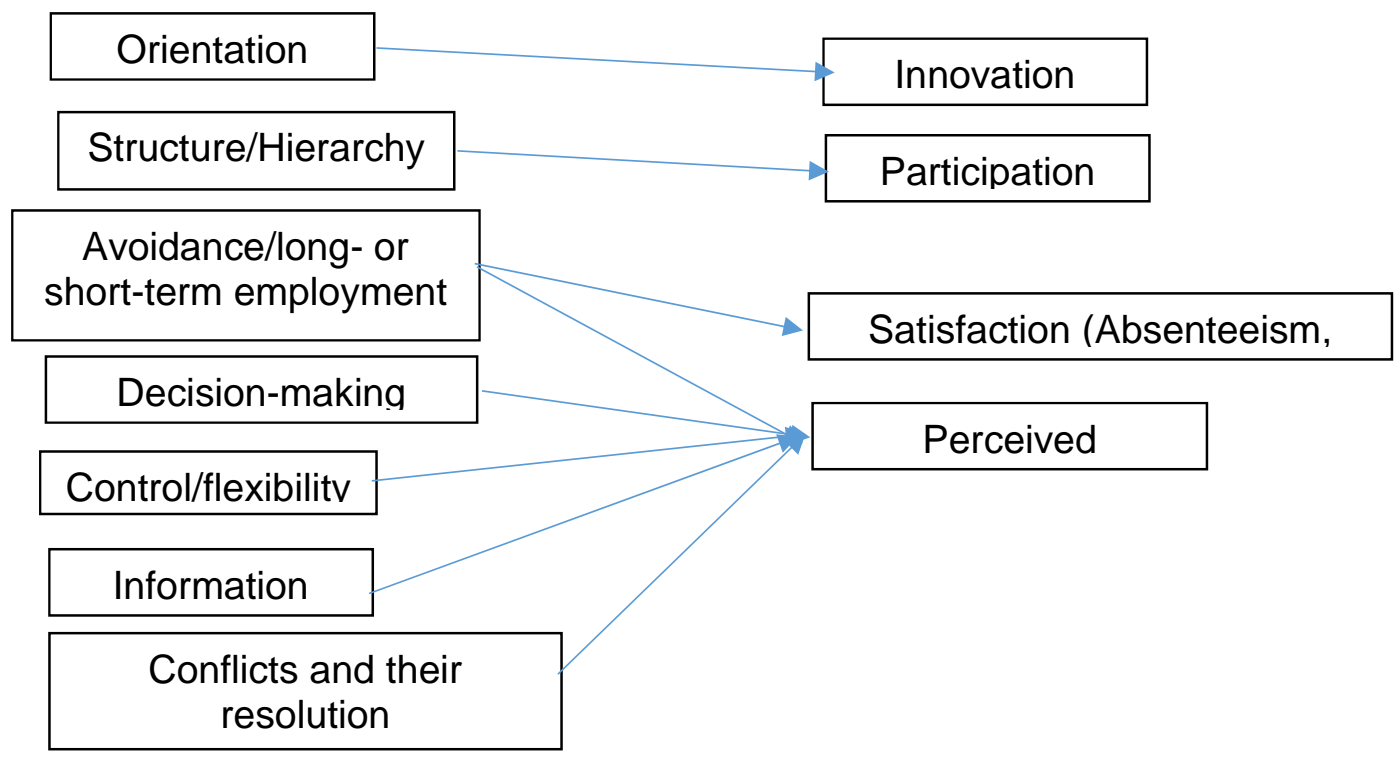

We also conducted an analysis utilizing the interviews with the 232 employees of Firm E; we used Spearman's rho since the indicators are qualitative, ordinal, and nominal.

In addition, we conducted a cross-tab analysis with the categorical ordinal variables in order to find relationships between them. The results show that there are correlations not only between indicators of organizational culture and indicators of performance, but also within the same groups (we do not show the result of all of the correlations due to space restrictions). 
Oberföll, K., Camarena Adame, M.E. \& Saavedra García, M.L. (2018) Relationship between organizational culture and performance among German multinational companies in Mexico. Journal of Business, Universidad del Pacífico (Lima, Peru) Vol.10(2): 24-47

The correlations that prove significant between the indicators of organizational culture and performance are shown in Graph 2. The influence of indicators of culture on employee satisfaction was predominant, so the notion that cultural factors influence performance through employee satisfaction is worthy of consideration.

Graph 2 shows the relationship between absenteeism and misunderstandings due to information failings, as well as that between turnover and misunderstandings, and conflict frequency; on the other hand, job satisfaction is related to external orientation, misunderstandings, rules, and conflict frequency; and finally, firm satisfaction is related to external orientation, rules, and conflict frequency. The only quantitative performance indicator is related to decision-making freedom.

\section{Graph 2. Relationship between organizational culture and performance}

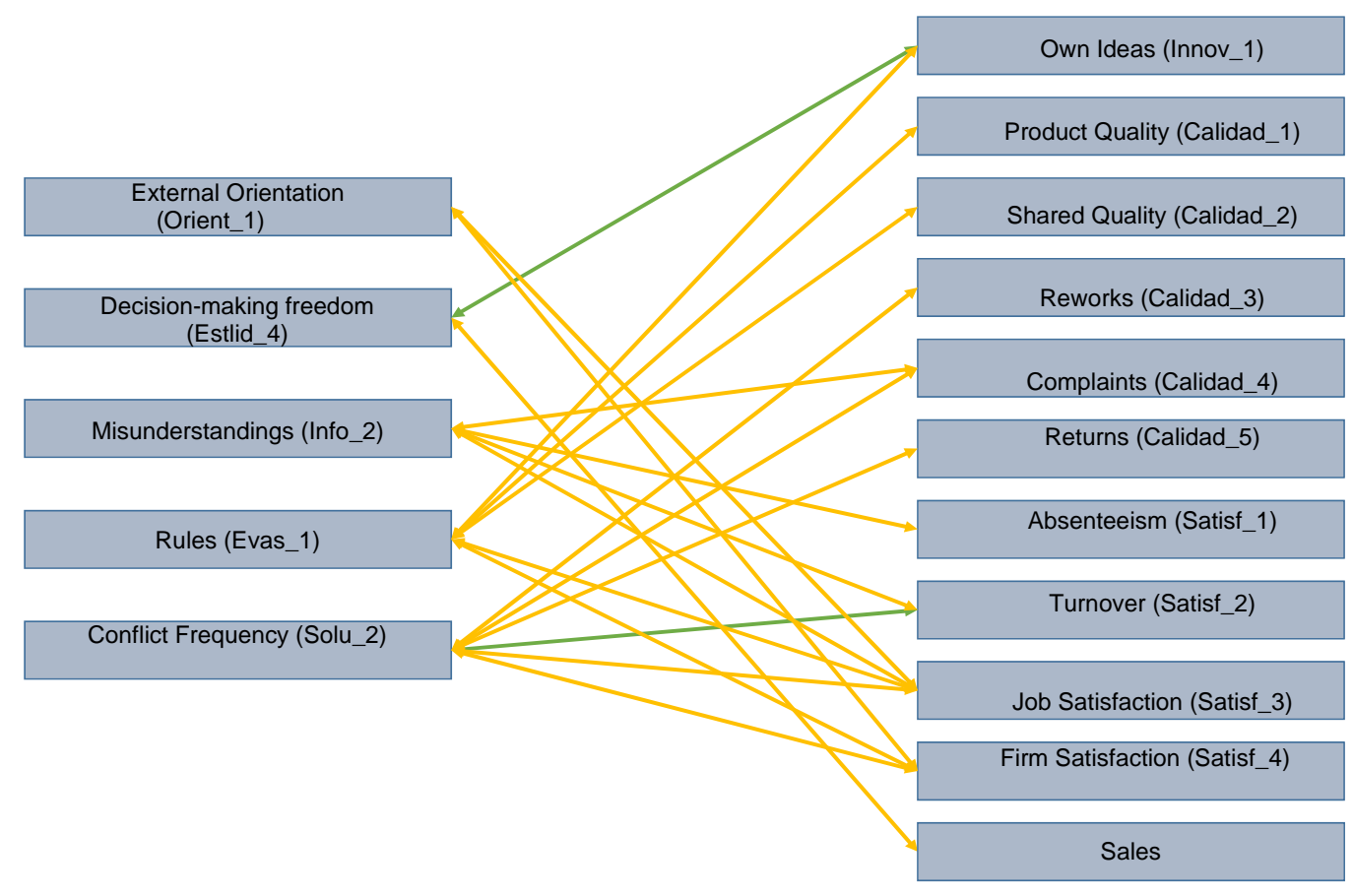

These results are considered as proof that a significant relationship exists between organizational culture and organizational performance, which confirms hypothesis $\mathbf{H}_{\mathbf{1}}$.

\section{Relationship between job satisfaction and firm values}

Hofstede (1980) proposes that a nation's cultural and subcultural dimensions influence the way in which organizational transactions are carried out (e.g., marketing, hiring practices, rewards programs, supervisor-employee interactions, and use of technology), and in turn, these transactions influence job satisfaction. 
To establish the relationship that exists between job satisfaction and firm values (whereby the latter are defined as individualism vs. collectivism, masculinity vs. femininity, power distance, uncertainty avoidance, and long-term vs. short-term orientation), we used a chi-squared method with a confidence level of $95 \%$ and an alpha error of $5 \%$. Below, we present only the results that proved significant.

In addition, we propose the following hypotheses:

$\mathrm{H}_{8}$ : There is a significant relationship between satisfaction with the job and the firm and with individualism vs. collectivism.

$\mathrm{H}_{9}$ : There is a significant relationship between satisfaction with the job and the firm and with masculinity vs. femininity.

$\mathrm{H}_{10}$ : There is a significant relationship between satisfaction with the job and the firm and with power distance.

$\mathrm{H}_{11}$ : There is a significant relationship between satisfaction with the job and the firm and with uncertainty avoidance.

$\mathrm{H}_{12}$ : There is a significant relationship between satisfaction with the job and the firm and with long-term vs. short-term orientation.

The crosstabs between satisfaction and individualism vs. collectivism clearly show that most of those who selected more individualist values for the firm are less satisfied (more or less satisfied), both with their job and with the firm. Those who selected more collectivist values are more satisfied (quite satisfied) both with the job and the firm (see Table 6). Thus, $\mathrm{H} 8$ cannot be rejected.

Table 6 Relationship between job/firm satisfaction and individualism vs. collectivism

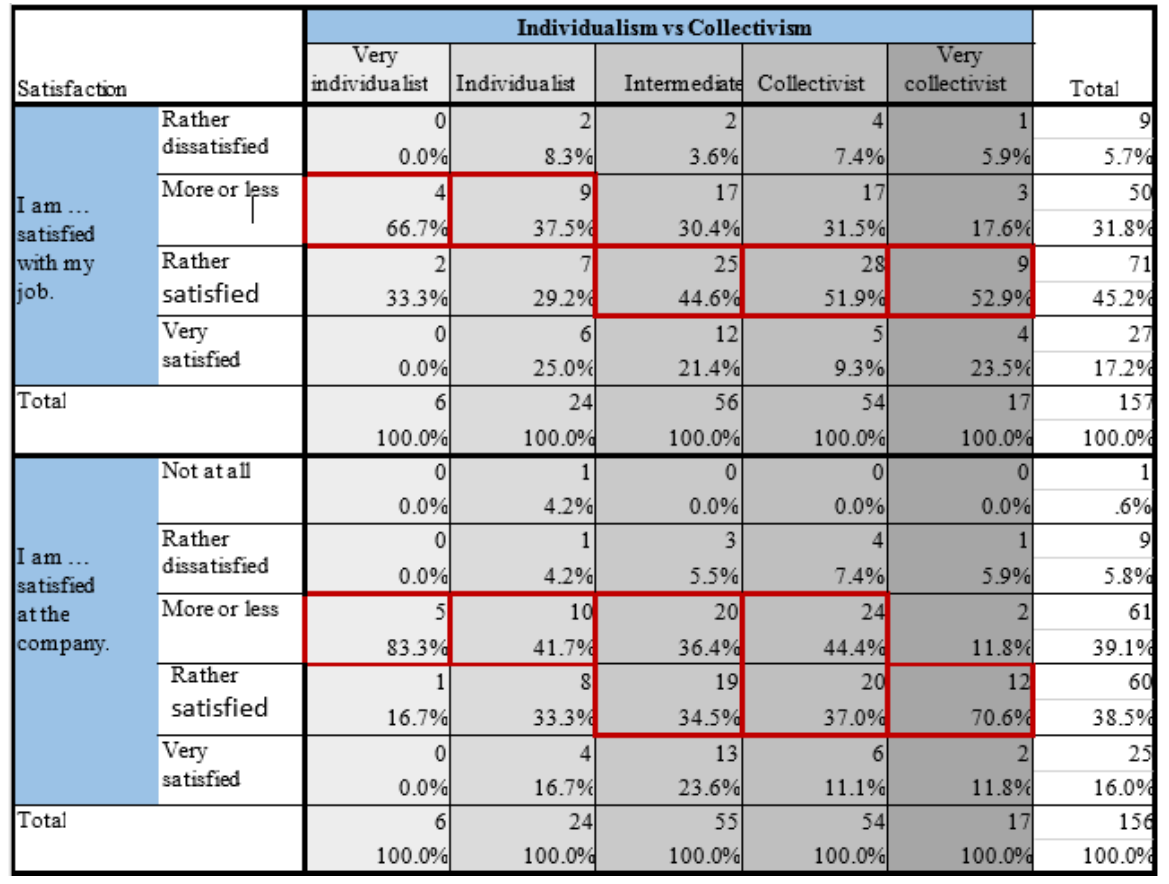

The same is observed in the case of masculinity vs. femininity; the participants who selected the more masculine factors express less satisfaction with their job and the firm (more or less satisfied), while those who selected more feminine factors are more 
satisfied with the job and the firm (quite satisfied) (see Table 7). Thus, H9 cannot be dismissed.

Table 7 Relationship between job/firm satisfaction and masculinity vs. femininity

\begin{tabular}{|c|c|c|c|c|c|c|c|}
\hline \multirow{2}{*}{ Satisfaction } & & \multicolumn{5}{|c|}{ Masculinity vs Femininity } & \multirow[b]{2}{*}{ Total } \\
\hline & & $\begin{array}{c}\text { Very } \\
\text { masculine }\end{array}$ & Masculine & Intermediate & Feminine & $\begin{array}{c}\text { Very } \\
\text { feminine }\end{array}$ & \\
\hline \multirow{4}{*}{$\begin{array}{l}\text { I am ... } \\
\text { satisfied } \\
\text { with my } \\
\text { job. }\end{array}$} & $\begin{array}{l}\text { Rather } \\
\text { dissatisfied }\end{array}$ & $\begin{array}{r}1 \\
2.8 \%\end{array}$ & $\begin{array}{r}3 \\
8.6 \% \\
\end{array}$ & $\begin{array}{r}2 \\
3.8 \%\end{array}$ & $\begin{array}{r}2 \\
7.7 \%\end{array}$ & $\begin{array}{r}1 \\
12.5 \%\end{array}$ & $\begin{array}{r}9 \\
5.7 \%\end{array}$ \\
\hline & $\begin{array}{l}\text { More or less } \\
\text { satisfied }\end{array}$ & $\begin{array}{r}16 \\
44.4 \%\end{array}$ & $\begin{array}{r}15 \\
42.9 \%\end{array}$ & $\begin{array}{r}12 \\
22.6 \%\end{array}$ & $\begin{array}{r}6 \\
23.1 \%\end{array}$ & $\begin{array}{r}1 \\
12.5 \%\end{array}$ & $\begin{array}{r}50 \\
31.6 \%\end{array}$ \\
\hline & $\begin{array}{l}\text { Rather } \\
\text { satisfied }\end{array}$ & $\begin{array}{r}10 \\
27.8 \%\end{array}$ & $\begin{array}{r}14 \\
40.0 \%\end{array}$ & $\begin{array}{r}28 \\
52.8 \%\end{array}$ & $\begin{array}{r}14 \\
53.8 \%\end{array}$ & $\begin{array}{r}5 \\
62.5 \%\end{array}$ & $\begin{array}{r}71 \\
44.9 \%\end{array}$ \\
\hline & $\begin{array}{l}\text { Very } \\
\text { satisfied }\end{array}$ & $\begin{array}{r}9 \\
25.0 \%\end{array}$ & $\begin{array}{r}3 \\
8.6 \%\end{array}$ & $\begin{array}{r}11 \\
20.8 \%\end{array}$ & $\begin{array}{r}4 \\
15.4 \%\end{array}$ & $\begin{array}{r}1 \\
12.5 \%\end{array}$ & $\begin{array}{r}28 \\
17.7 \%\end{array}$ \\
\hline Total & & $\begin{array}{r}36 \\
100.0 \%\end{array}$ & $\begin{array}{r}35 \\
100.0 \%\end{array}$ & $\begin{array}{r}53 \\
100.0 \%\end{array}$ & $\begin{array}{r}26 \\
100.0 \%\end{array}$ & $\begin{array}{r}8 \\
100.0 \%\end{array}$ & $\begin{array}{r}158 \\
100.0 \%\end{array}$ \\
\hline \multirow{5}{*}{$\begin{array}{l}\text { I am .... } \\
\text { satisfied } \\
\text { at the } \\
\text { company. }\end{array}$} & $\begin{array}{l}\text { Not at all } \\
\text { satisfied }\end{array}$ & $\begin{array}{r}0 \\
0.0 \%\end{array}$ & $\begin{array}{r}1 \\
2.9 \%\end{array}$ & $\begin{array}{r}0 \\
0.0 \%\end{array}$ & $\begin{array}{r}0 \\
0.0 \%\end{array}$ & $\begin{array}{r}0 \\
0.0 \%\end{array}$ & $\begin{array}{r}1 \\
.6 \%\end{array}$ \\
\hline & $\begin{array}{l}\text { Rather } \\
\text { dissatisfied }\end{array}$ & $\begin{array}{r}2 \\
5.6 \%\end{array}$ & $\begin{array}{r}2 \\
5.7 \%\end{array}$ & $\begin{array}{r}2 \\
3.8 \%\end{array}$ & $\begin{array}{r}2 \\
7.7 \%\end{array}$ & $\begin{array}{r}1 \\
12.5 \%\end{array}$ & $\begin{array}{r}9 \\
5.7 \%\end{array}$ \\
\hline & $\begin{array}{l}\text { More or less } \\
\text { satisfied }\end{array}$ & $\begin{array}{r}16 \\
44.4 \%\end{array}$ & $\begin{array}{r}19 \\
54.3 \%\end{array}$ & $\begin{array}{r}17 \\
32.7 \%\end{array}$ & $\begin{array}{r}8 \\
30.8 \%\end{array}$ & $\begin{array}{r}1 \\
12.5 \%\end{array}$ & $\begin{array}{r}61 \\
38.9 \% \\
\end{array}$ \\
\hline & $\begin{array}{l}\text { Rather } \\
\text { satisfied }\end{array}$ & $\begin{array}{r}11 \\
30.6 \%\end{array}$ & $\begin{array}{r}9 \\
25.7 \% \\
\end{array}$ & $\begin{array}{r}23 \\
44.2 \% \\
\end{array}$ & $\begin{array}{r}11 \\
42.3 \% \\
\end{array}$ & $\begin{array}{r}6 \\
75.0 \% \\
\end{array}$ & $\begin{array}{r}60 \\
38.2 \% \\
\end{array}$ \\
\hline & $\begin{array}{l}\text { Very } \\
\text { satisfied }\end{array}$ & $\begin{array}{r}7 \\
19.4 \%\end{array}$ & $\begin{array}{r}4 \\
11.4 \%\end{array}$ & $\begin{array}{r}10 \\
19.2 \%\end{array}$ & $\begin{array}{r}5 \\
19.2 \%\end{array}$ & $\begin{array}{r}0 \\
0.0 \%\end{array}$ & $\begin{array}{r}26 \\
16.6 \%\end{array}$ \\
\hline \multicolumn{2}{|l|}{ Total } & $\begin{array}{r}36 \\
100.0 \%\end{array}$ & $\begin{array}{r}35 \\
100.0 \%\end{array}$ & $\begin{array}{r}52 \\
100.0 \%\end{array}$ & $\begin{array}{r}26 \\
100.0 \%\end{array}$ & $\begin{array}{r}8 \\
100.0 \%\end{array}$ & $\begin{array}{r}157 \\
100.0 \%\end{array}$ \\
\hline
\end{tabular}

Power distance, which denotes fear of expressing disagreement with a superior, indicates that the more fear that employees have, the less satisfied they will be. Thus, $55 \%$ of those who almost always feel fear are more or less content with the job and the firm. Meanwhile, 45 and $55 \%$ of those who stated they never or sometimes felt fear are quite content with their work and the firm, which is evidenced by their lower level of workplace stress (see Table 8); as such, $\mathbf{H}_{\mathbf{1 0}}$. cannot be rejected.

Table 8 Relationship between job/firm satisfaction and power distance

\begin{tabular}{|c|c|c|c|c|c|c|c|}
\hline \multirow{2}{*}{ Satisfaction } & & \multicolumn{5}{|c|}{ Power distance (fear of expressing disagreement, } & \multirow[b]{2}{*}{ Total } \\
\hline & & Never & Almostnever & Sometimes & Almost always & Always & \\
\hline \multirow{8}{*}{$\begin{array}{l}\text { I am ... } \\
\text { satisfied } \\
\text { with my } \\
\text { job. }\end{array}$} & Rather & 2 & 1 & $\overline{3}$ & 2 & 1 & 9 \\
\hline & Dissatisfied & $5.1 \%$ & $3.1 \%$ & $4.1 \%$ & $22.2 \%$ & $16.7 \%$ & $5.7 \%$ \\
\hline & Moreorlese & 10 & 8 & 26 & 5 & 2 & 51 \\
\hline & $\begin{array}{l}\text { More or less } \\
\text { satisfied }\end{array}$ & $25.6 \%$ & $25.0 \%$ & $35.6 \%$ & $55.6 \%$ & $33.3 \%$ & $32.1 \%$ \\
\hline & Rather & 19 & 17 & 32 & 2 & 2 & 72 \\
\hline & satisfied & $48.7 \%$ & $53.1 \%$ & $43.8 \%$ & $22.2 \%$ & $33.3 \%$ & $45.3 \%$ \\
\hline & Very & 8 & 6 & 12 & 0 & 1 & 27 \\
\hline & satisfied & $20.5 \%$ & $18.8 \%$ & $16.4 \%$ & $0.0 \%$ & $16.7 \%$ & $17.0 \%$ \\
\hline \multirow[t]{2}{*}{ Total } & & 39 & 32 & 73 & 9 & 6 & 159 \\
\hline & & $100.0 \%$ & $100.0 \%$ & $100.0 \%$ & $100.0 \%$ & $100.0 \%$ & $100.0 \%$ \\
\hline \multirow{10}{*}{$\begin{array}{l}\text { I am .... } \\
\text { satisfied } \\
\text { at the } \\
\text { company. }\end{array}$} & Notat all & $\overline{0}$ & 1 & $\overline{0}$ & $\overline{0}$ & 0 & 1 \\
\hline & satisfied & $0.0 \%$ & $3.1 \%$ & $0.0 \%$ & $0.0 \%$ & $0.0 \%$ & $.6 \%$ \\
\hline & Rather & 2 & 1 & 3 & 2 & 1 & 9 \\
\hline & dissatisfied & $5.3 \%$ & $3.1 \%$ & $4.1 \%$ & $22.2 \%$ & $16.7 \%$ & $5.7 \%$ \\
\hline & More or less & 11 & 11 & 31 & 5 & 3 & 61 \\
\hline & satisfied & $28.9 \%$ & $34.4 \%$ & $42.5 \%$ & $55.6 \%$ & $50.0 \%$ & $38.6 \%$ \\
\hline & Rather & 17 & $\overline{16}$ & 25 & 1 & 2 & 61 \\
\hline & sat & $44.7 \%$ & $50.0 \%$ & $34.2 \%$ & $11.1 \%$ & $33.3 \%$ & $38.6 \%$ \\
\hline & Very & 8 & 3 & 14 & 1 & 0 & 26 \\
\hline & satisfied & $21.1 \%$ & $9.4 \%$ & $19.2 \%$ & $11.1 \%$ & $0.0 \%$ & $16.5 \%$ \\
\hline \multirow{2}{*}{\multicolumn{2}{|c|}{ Total }} & 38 & 32 & 73 & 9 & 6 & 158 \\
\hline & & $100.0 \%$ & $100.0 \%$ & $100.0 \%$ & $100.0 \%$ & $100.0 \%$ & $100.0 \%$ \\
\hline
\end{tabular}


Oberföll, K., Camarena Adame, M.E. \& Saavedra García, M.L. (2018) Relationship between organizational culture and performance among German multinational companies in Mexico. Journal of Business, Universidad del Pacífico (Lima, Peru) Vol.10(2): 24-47

The significance levels of hypotheses $\mathbf{H}_{11}$ and $\mathbf{H}_{12}$ were greater than $p>0.05$, so these hypothesis can be rejected.

\section{Conclusions and implications}

Our analysis of the organizational culture of the firms shows that the composition of the group of employees is rather homogeneous, with a limited presence of individuals of different nationalities; thus, Hypothesis 2 is rejected. In turn, hypothesis 3 is confirmed, since organizational culture is influenced by German and Mexican culture. This can be seen in the prevalence of values associated with the two countries: power distance tends to be high and companies are mostly collectivist, distinctive features of Mexico; while masculinity and uncertainty evasion, both distinctive features of Germany, also predominate.

The prevailing factors in all cases were: dependence on the parent company, leading to a vertical and centralized hierarchy; and the high degree of control and planning, leading to intermediate freedom in decision-making. It is also notable that all firms were very customer-oriented and somewhat product-specialized. We also confirmed that the firms established themselves in Mexico for reasons of cost reduction and to be close to their customers.

As to conflicts, we rejected $\mathrm{H} 4$, having found that conflicts arise not because of cultural differences, but because of work issues such as failures in the flow of information, differing senses of urgency, unclear responsibilities, and gossip and suspicion at operational levels, which result in delays in the manufacturing or service process.

As to firm performance, quality is good, which is reflected in low percentages of rework, waste and complaints. Market share differs greatly from one company to another, with differences arising from the influence of the main customer, target market, and structure of each firm.

As to employee satisfaction, there are differences across positions and between permanent and outsources workers. Satisfaction is also related to indicators of organizational culture; uncertainty avoidance influences it, with outsourced workers the least satisfied, and those with long service as permanent employees found to be the most satisfied.

It is not possible to maintain the proposed structure of variables composed of the stated indicators. There are only relationships between $\mathrm{H} 5$ (influence of the structure on performance), H6 (influence of values on performance) and $\mathrm{H} 7$ (influence of conflicts and their resolution on performance). However, through our analyses (qualitative, categorical variable and correlations), we found relationships between indicators of culture and performance. This correlation is consistent, although we did not determine any causality.

In sum, we confirm that organizational culture has a significant influence on performance, and thus cannot discard hypothesis $\mathrm{H} 1$. We propose the following recommendations. Because structure is so important for market share, the firms ought to be very clearly delimited: the responsibilities of each department and post must be taken into account; the flow of information must be without interruptions; and even if the company is growing or downsizing, this structure must have adaptation mechanisms in place. 
Oberföll, K., Camarena Adame, M.E. \& Saavedra García, M.L. (2018) Relationship between organizational culture and performance among German multinational companies in Mexico. Journal of Business, Universidad del Pacífico (Lima, Peru) Vol.10(2): 24-47

Finally, we found a relationship between the level of individualism vs. collectivism, masculinity vs. femininity, employee satisfaction, and fear of one's superior. The values of collectivism should be strengthened in order to increase employee satisfaction and retain their employment.

\section{Limitations and future lines of research}

The main limitation of this study concerns the mixed design of the questionnaire, which included open, dichotomous, ordinal questions, making it difficult to establish relationships; moreover, as a multiple-case study, it is not possible to generalize the findings. Another limitation involved the impossibility of obtaining indicators of financial performance to establish their relationship with organizational culture. However, further research would be required to work with specific indicators to identify variables; for example, increasing the number of ordinal indicators to form groups of variables, and establishing an exact model on the relationships between these variables through a new survey based on these indicators. Another line of research is oriented towards the study of values as the core of organizational culture and its influence on performance.

\section{References}

Allaire, I. \& Firsirotu, M. E. (1984). Theories of Organizational Culture. Organization Studies, 5(3), 193-226.

Boyce, S. A., Nieminen, G. L., Gillespie, A. G., Ryan, M.A. \& Denison, R. D. (2015). Which comes first, organizational culture or performance? A longitudinal study of causal priority with automobile dealerships. Journal of Organizational Behavior, 36(3), 339-359. DOI: $10.1002 / j o b .1985$

Calori, R. \& Sarnin, P. (1991). Corporate Culture and Economic Performance: A French Study. Organization Studies, 12(1), 49-74. DOI: 10.1177/017084069101200104

Cameron, K. \& Quinn, R. (2011). Diagnosing and changing organizational culture: based on the competing values framework. 3rd Edition. USA: Wiley John.

Cheung, O., Wong, P. \& Lam, L. (2012). An investigation of the relationship between organizational culture and the performance of construction organizations. Journal of Business Management, 13(4), 688-704.

Chow, W.C., Haddad, M. K. \& Wu, A. (2002). Corporate Culture and Performance: Evidence from Taiwanese Manufacturing Companies. Journal of Asia-Pacific Business, 4(4), 25- 38. DOI: 10.1300/J098v04n04_03

Connaughton, S. L. \& Shuffler, M. (2007), Multicultural and Multinational Distributed Teams, A Review and Future Agenda. Small Group Research, 38(3), 387-412. DOI: $10.1177 / 1046496407301970$

Cooke, R. A, \& Rousseau, D. M. (1988). Behavioral Norms and Expectations: A quantitative approach to the assessment of organizational culture. Group \& Organization Studies, 13 (3), 245-273. DOI: 10.1177/105960118801300302 
Oberföll, K., Camarena Adame, M.E. \& Saavedra García, M.L. (2018) Relationship between organizational culture and performance among German multinational companies in Mexico. Journal of Business, Universidad del Pacífico (Lima, Peru) Vol.10(2): 24-47

Cunha, R. C. \& Cooper, C. L. (2002). Does privatization affect corporate culture and employee wellbeing? Journal of Managerial Psychology, 17 (1), 21-49. DOI: $10.1108 / 02683940210415915$

Deal, T. E. \& Kennedy, A. A. (1982). Corporate Cultures, The Rites and Rituals of Corporate Life. USA: Addison-Wesley Publishing Company, Inc.

Denison, D. (1984). Bringing Corporate Culture to the Bottom Line. Organizational Dynamics, 13(2)4-22. DOI: 10.1016/0090-2616(84)90015-9

Denison, D. (1991). Cultura corporativa y productividad organizacional. Bogotá, Colombia: Legis Editores.

Denison, D., Janovics, J., y Young, J. (2005). Diagnosing Organizational Cultures: Validating a Model and Method. Working paper. New York: Denison Consulting Group.

Denison, D., Nieminen, L., \& Kotrba, L. (2014). Diagnosing organizational cultures: A conceptual and empirical review of culture effectiveness surveys. European Journal of Work \& Organizational Psychology, 23(1), 145-161. DOI: $10.1080 / 1359432 X .2012 .713173$

Deutsch-Mexikanische Industrie- und Handelskammer. (2012). Zielmarktanalyse im Rahmen der Geschäftsanbahnung Automobilzulieferer Mexiko. Die mexikanische Automobil- und Automobilzulieferindustrie und Potenziale für deutsche Unternehmen. Retrieved from: http://www.autocluster.nrw.de/fileadmin/images/PDF/MarktstudieAutomobilzulieferer- Mexiko.pdf

Franke, R., Hofstede, G. \& Bond, M. (1991). Cultural Roots of Economic Performance: A Research Note. Strategic Management Journal, 12, 165-173. DOI: 10.1002/smj.4250120912

Friedich E. (2010). Zukunft der deutschen Automobilindustrie. Herausforderungen und Perspektiven für den Strukturwandel im Automobilsektor. Germany: Friedich Ebert Stiffung. Retrieved from http://library.fes.de/pdf-files/wiso/07703.pdf

Gálvez, E. J. \& García Pérez de Lema, D. (2011). Cultura organizacional y rendimiento de las MIPYMES de mediana y alta tecnología: un estudio empírico en Cali, Colombia. Cuadernos de administración 24(42), 125-145.

Geertz, C. (1973). The Interpretation of Cultures. Barcelona: Gedisa.

Germany Trade \& Invest, Automobil-Industrie. Retrieved from http://www.gtai.de/GTAl/ Navigation/EN/Invest/Industries/Mobility/automotive.html

Ginevicius, R. \& Vaitkunaite, V. (2006). Analysis of organizational culture dimensions impacting performance. Journal of Business Economics and Management, VII(4), 201211.

Gómez, I. \& Ricardo, R. (2012). Cultura organizacional: Aproximación sectorial en Bogotá. Revista Facultad de Ciencias Económicas: Investigación y Reflexión, 20(2), 1941.

Gordon, G. \& Di Tomaso, N. (1992). Predicting corporate performance from organizational culture. Journal of Management Studies, 29(6), 783-798. DOI: 10.1111/j.1467-6486.1992.tb00689.x 
Oberföll, K., Camarena Adame, M.E. \& Saavedra García, M.L. (2018) Relationship between organizational culture and performance among German multinational companies in Mexico. Journal of Business, Universidad del Pacífico (Lima, Peru) Vol.10(2): 24-47

Gregory, B., Harris, S., Armenakis, A., \& Shook, C. (2009). Organizational culture and effectiveness: A study of values, attitudes and organizational outcomes. Journal of Business Research, 62, 673-679. DOI: 10.1016/j.jbusres.2008.05.021

Hamann, P., Schiemann, F., Bellora, L. \& Guenther, T. (2013). Exploring the Dimensions of Organizational Performance: A Construct Validity Study. Organizational Research Methods, 16(1), 67-87. DOI: 10.1177/1094428112470007

Harrison, R. (1972). Understanding your organisation's character. Boston: Harvard Business Review.

Hofstede, G. (1980). Cultures consequences: International differences in work related values. California: Sage Publications, Inc.

Hofstede, G. (2001). Cultures consequences. Comparing values, behaviors, institutions, and organizations across nations. Beverly Hills: Sage.

Hofstede, G., \& Hofstede, G. (2005). Cultures and Organizations, Software of the Mind. United States: McGraw Hill.

Jacobs, R., Mannion, R., Davies, H., Harrison, S., Konteh, F. \& Walshe, K. (2013). The relationship between organizational culture and performance in acute hospitals. Social Science \& Medicine, 76, 115-125. DOI: 10.1016/j.socscimed.2012.10.014

Kotter, J. \& Heskett, J. (1992). Corporate Culture and Performance. United States: The Free Press.

Kroeber, A. \& Kluckhohn, C. (1952). Culture - A Critical Review of Concepts and Definitions. New York: Vintage Books.

Langat, E. \& Lagat, C. (2017). Effect of Organizational Ownership and Culture on Employee Performance Among Selected Banks in Kenya. European Scientific Journal,13 (13)409-425.

Leithy, W. (2017) Organizational Culture and Organizational Performance. International Journal of Economic \& Management Sciences, 6 (4)1-6. doi: 10.4172/21626359.1000442

Marculides, G. \& Heck, R. (1993). Organizational Culture and Performance: Proposing and testing a model. Organizational Science, 4(2), 209-225. DOI: 10.1287/orsc.4.2.209

Martin, J. \& Siehl, C. (1983). Organizational Culture and Counterculture: An Uneasy Symbiosis. Organizational Dynamics, 12(2), 52-64. DOI: 10.1016/0090-2616(83)900335

Martínez, M. (2010). Relaciones entre cultura y desempeño organizacional en una muestra de empresas colombianas: reflexiones sobre la utilización del modelo de Denison. Cuadernos de Administración, 23(40), 163-190.

Mobley, W., Wang, L., \& Fang, K. (2005). Organizational Culture: Measuring and Developing It in Your Organization. Harvard Business Review China. (March 2005), 128139. 
Oberföll, K., Camarena Adame, M.E. \& Saavedra García, M.L. (2018) Relationship between organizational culture and performance among German multinational companies in Mexico. Journal of Business, Universidad del Pacífico (Lima, Peru) Vol.10(2): 24-47

Naranjo, J., Jiménez, D. y Sanz, R. (2016). Studying the links between organizational culture, innovation, and performance in Spanish companies. Revista Latinoamericana de Psicología (2016) 48, 30-41.

Nazir, N. \& Lone, M. (2008). Validation of Denison's Model of organizational culture and effectiveness in the Indian context. Vision, 12(1), 49-58.DOI: 10.1177/097226290801200107

Ogaad, T., Larsen, S. \& Marnburg, E. (2005). Organizational culture and performance evidence from the fast food restaurant industry. Food Service Technology, 5(1), 23-34. DOI: 10.1111/j.1471-5740.2005.00109.x/

Ozigbo, N. (2013). Impact of Organizational Culture and Technology on Firm Performance in the Service Sector. Communications of the IIMA, 13(1), 69-81.

ProMexico (2013). Industria Farmacéutica. Unidad de inteligencia de negocios. Mexico City: ProMexico.

PWC (2013). Doing Business in Mexico. Automotive Industry. Mexico City: Pricewaterhouse Coopers. Retrieved from: http://www.pwc.com/mx/es/publicaciones/archivo/2013-05-doingbusinessautomotriz.pdf

Sai On Cheung, S., Wong, S.P. \& Lam, L. A. (2012). An investigation of the relationship between organizational culture and the performance of construction organizations. Journal of Business Management, 13(4), 688-704. DOI: 10.3846/16111699.2011.620157

Schein, E. (1984). Coming to a new awareness of organizational culture. Sloan Management Review, 25 (2)3-15.

Schein, E. (2004). Organizational Culture and Leadership, a dynamic view. San Francisco, USA: Editorial John Wiley \& Sons, Inc.

Schindler, J. (2012). Deutsch-Mexikanische Industrie- und Handelskammer. Zielmarktanalyse im Rahmen der Geschäftsanbahnung Automobilzulieferer Mexiko. Die mexikanische Automobil- und Automobilzulieferindustrie und Potenziale für deutsche Unternehmen. Mexico: German Centre. Retrieved from :http://www.autocluster.nrw.de/fileadmin/images/PDF/MarktstudieAutomobilzule fererMexiko.pdf

Smircich, L. (1983). Concepts of Culture and Organizational Analysis. Administrative Science Quarterly, 28(3), 339-358. DOI: 10.2307/2392246

Van Den Berg, P. T. \& Wilderom, P. M. (2004). Defining, Measuring and Comparing Organisational Cultures. Applied Psychology: An International Review, 53 (4), 570-582. DOI: 10.1111/j.1464-0597.2004.00189.x

Wei, Y., Samiee, S. \& Lee, R. (2012). The influence of organic organizational cultures, market responsiveness, and product strategy on firm performance in an emerging market. Journal of the Academy of Marketing Science, 42(1), 49-70.

Winston, E. \& Dadzie, K. (2007). Organizational Culture in Cote d'Ivoire: Analysis of Cultural Types and Firm Performance. Journal of African Business, 8(1), 99-112. DOI: 10.1300/J156v08n01_06 
Oberföll, K., Camarena Adame, M.E. \& Saavedra García, M.L. (2018) Relationship between organizational culture and performance among German multinational companies in Mexico. Journal of Business, Universidad del Pacífico (Lima, Peru) Vol.10(2): 24-47

Yesil, S. \& Kaya, A. (2013). The Effect of Organizational Culture on Firm Financial Performance: Evidence from a Developing Country. Social and Behavioral Sciences, 81, 428-437. DOI: 10.1016/j.sbspro.2013.06.455 